\title{
STAVOVI NASTAVNIKA GEOGRAFIJE O RADU S UČENICIMA S TEŠKOĆAMA U RAZVOJU
}

\author{
Dominko Svilan, Ana Pejdo ${ }^{1}$, Jadranka Brkić-Vejmelka ${ }^{2}$ \\ ${ }^{1}$ Odjel za geografiju, Sveučilište u Zadru, Hrvatska \\ ${ }^{2}$ Odjel za nastavničke studije u Gospiću, Sveučilište u Zadru, Hrvatska \\ dominkosvilan@yahoo.com; apejdo@unizd.hr; jbrkic@unizd.hr
}

Primljeno: 22. 1. 2021.

\begin{abstract}
Za uspješnu primjenu koncepta inkluzivnog obrazovanja, uz materijalne i tehničke uvjete, vrlo je važna kvaliteta $i$ unapređenje odgojno obrazovne prakse, temeljna znanja o odgoju i obrazovanju djece s teškoćama, kao i kompetentnost svih dionika u procesu odgoja i obrazovanja. Nastavnici su ključni dio odgojno-obrazovnog procesa pa su njihova stečena znanja $i$ vještine od velike važnosti za uspjeh primjene koncepta inkluzivnog obrazovanja. Cilj ovoga rada bio je utvrditi stavove nastavnika geografije osnovnih i srednjih škola o radu s učenicima s teškoćama u razvoju te analizirati koje nastavne metode koriste i u kojoj mjeri ih prilagođavaju učenicima s teškoćama u razvoju. Istraživanje je provedeno metodom anketnog upitnika, a obuhvatilo je nastavnike osnovnih $i$ srednjih škola u Hrvatskoj $(N=110)$. Rezultati istraživanja pokazuju da se nastavnici ne smatraju dovoljno kompetentnima za svakodnevni rad s djecom s teškoćama te izražavaju potrebu za dodatnim edukacijama $i$ usavršavanjima. $U$ svakodnevnom radu nastoje prilagoditi nastavne sadržaje $i$ metode poučavanja pojedinim teškoćama djece. Nastavnici smatraju kako je za uspjeh u poučavanju potrebna veća suradnja sa školskom stručnopedagoškom službom i s roditeljima. Kod pojedinih tvrdnji utvrđene su razlike u stavovima nastavnika koji rade u osnovnim u odnosu na one zaposlene u srednjim školama.
\end{abstract}

Ključne riječi: učenici s teškoćama u razvoju, geografija, nastava, stavovi nastavnika 


\section{Uvod}

Ključni čimbenik provođenja inkluzivnog obrazovanja je primjereno osposobljavanje i obrazovanje učitelja i nastavnika u formalnom sustavu odgoja i obrazovanja (Ainscow, 1994 u: Karamatić Brčić, 2012,42 ) odnosno profesionalno usavršavanje nastavnika i ravnatelja (Deppeler et al., 2005 u: Phillips i Cranby, 2015) kako bi se mijenjali nastavnički stavovi o potencijalu obrazovanja djece s teškoćama u razvoju. Prema Pravilniku o osnovnoškolskom i srednjoškolskom odgoju i obrazovanju učenika s teškoćama u razvoju (NN 24/2015) učenik s teškoćama u razvoju je ono dijete »čije sposobnosti u međudjelovanju s čimbenicima iz okoline ograničavaju njegovo puno, učinkovito i ravnopravno sudjelovanje u odgojno-obrazovnom procesu s ostalim učenicima«. Niz je teškoća koje dijete može imati. Podijeljene su u sljedeće skupine: »oštećenja vida, oštećenja sluha, oštećenja jezično-govorneglasovne komunikacije i specifične teškoće u učenju, oštećenja organa i organskih sustava, intelektualne teškoće, poremećaji u ponašanju i oštećenja mentalnog zdravlja te postojanje više vrsta teškoća u psihofizičkom razvoju« (NN 24/2015).

Pojam obrazovne inkluzije proširuje i produbljuje model obrazovne integracije kako teorijskim promišljanjima tako i praktičnim rješenjima (Karamatić Brčić, Viljac, 2018) s ciljem što potpunijeg, cjelokupnog uključivanja u obrazovni sustav djece s teškoćama (Zrilić, Brzoja, 2013). Međutim, problem koji se javlja tijekom poučavanja učenika s teškoćama je da nastavnici koriste identične strategije, metode i postupke poučavanja kao i kod ostale djece (Davis, Florian, 2004). Kako bi učenici s teškoćama mogli ravnopravno sudjelovati u nastavi geografije, nastavnik mora postaviti obrazovne ishode prilagođene potrebi pojedinca te pronaći rješenja zaprekama koje se javljaju tijekom procesa poučavanja i posebice vrednovanja (Training and Development Agency for Schools, 2009; Velki, 2018). Osim toga, jedan od problema s kojima se susreću nastavnici u svome radu je sve veći broj učenika s teškoćama uključenih u redoviti obrazovni sustav (Resnik Planinc, Kolnik, 2016).

Istraživanja provedena 1980-ih utvrdila su da su stavovi učitelja prema poučavanju učenika s teškoćama pretežito negativni. Međutim njihovi se stavovi mijenjaju i tijekom posljednjeg desetljeća pretežno su pozitivni uz stalno naglašavanje problema kako izvesti prilagodbu poučavanja tijekom rada $\mathrm{s}$ djecom $\mathrm{s}$ teškoćama u razvoju (Kiš-Gla- 
vaš, Wagner Jakab, 2001). Na uzorku od 775 nastavnika u osnovnim i srednjim školama Schumm i Vaughn (1992) utvrdili su da nastavnici u svom razredu žele imati učenike s teškoćama ukoliko učenici nemaju problema s ponašanjem ili emocionalnim ispadima. Istraživanja na temu rada s učenicima s teškoćama u nastavi geografije u Hrvatskoj su rijetka. Milić (2018) daje prijedlog načina procjene kompetencija učenika s teškoćama u nastavi geografije, a Torma (2019) daje niz prijedloga kako individualizirati poučavanje učenika sa specifičnim teškoćama u učenju u nastavi geografije.

Prema Pravilniku o obrazovanju djece s teškoćama u razvoju u osnovnoj i srednjoj školi za učenike s teškoćama u razvoju primjenjuje se nastavni plan i program i/ili kurikulum koji omogućuje odgojnoobrazovno napredovanje učenika poštujući specifičnosti njegove teškoće i odgojno-obrazovne potrebe. Programi za djecu s teškoćama u razvoju dijele se na: redovite programe uz individualizirane postupke, redovite programe uz prilagodbu sadržaja i individualizirane postupke, posebne programe uz individualizirane postupke i posebne programe za stjecanje kompetencija u aktivnostima svakodnevnog života rada uz individualizirane postupke (NN 24/15, čl. 3., st. 3. i 4.).

Prilikom istraživanja pojedinih tema koje se odnose na područje obrazovanja potrebno je analizirati demografske pokazatelje poput primjerice ukupnog broja djece, tj. u ovom slučaju ukupnog broja učenika u osnovnim i srednjim školama i učenika s teškoćama u razvoju integriranih u redoviti obrazovni sustav. Veličina učeničkog kontingenta utječe na potrebu za nastavnicima geografije (Spevec, Vuk, 2012; Vranković, 2017), dok broj djece s teškoćama uključenih u redovni obrazovni sustav utječe na ukupnu opterećenost i kvalitetu rada u razrednom odjeljenju. Promatrajući kretanje ukupnog broja učenika u Republici Hrvatskoj (Tablica 1) zamjetan je pad tog broja dok je u istom razdoblju zabilježen rast broja učenika s teškoćama u razvoju (Milić, 2018). Ova je pojava očekivana s obzirom da se u promatranom razdoblju počeo primjenjivati Pravilnik o osnovnoškolskom i srednjoškolskom odgoju $i$ obrazovanju učenika s teškoćama u razvoju (NN 24/15) i Pravilnik o pomoćnicima u nastavi i stručnim komunikacijskim posrednicima (NN 102/2018). 
Tablica 1. Ukupan broj učenika u osnovnim školama i učenika s teškoćama integriranih u osnovne škole u razdoblju od školske godine 2011./2012. do 2018./2019.

\begin{tabular}{|c|c|c|}
\hline $\begin{array}{c}\text { Školska } \\
\text { godina }\end{array}$ & $\begin{array}{c}\text { Ukupan broj } \\
\text { učenika }\end{array}$ & $\begin{array}{c}\text { Ukupan broj učenika s } \\
\text { teškoćama u razvoju }\end{array}$ \\
\hline $2011 . / 2012$. & 342028 & 15377 \\
\hline $2012 . / 2013$. & 334070 & 15592 \\
\hline $2013 . / 2014$. & 327204 & 16318 \\
\hline $2014 . / 2015$. & 323195 & 16431 \\
\hline $2015 . / 2016$. & 320017 & 17124 \\
\hline $2016 . / 2017$. & 319204 & 17556 \\
\hline $2017 . / 2018$. & 317541 & 18312 \\
\hline $2018 . / 2019$. & 316104 & 18656 \\
\hline
\end{tabular}

Izvor: Državni zavod za statistiku, 2020a, 2020b, 2019a, 2019b, 2018a, 2018b, 2017a, 2017b, 2016a, 2016b, 2015a, 2015b, 2014a, 2014b, 2013a, $2013 b$

Najizraženiji je porast broja učenika s teškoćama u razvoju integriranih u redovni obrazovni sustav u srednjim školama gdje se broj učenika s teškoćama u promatranom razdoblju od 2011./2012. do 2018./2019. povećao s 1779 na 5626 (Tablica 2). Zakonska regulativa omogućila je bolju evidenciju učenika s teškoćama u razvoju i njihovo brže uključivanje u redoviti odgojno-obrazovni sustav. Niz je čimbenika koji moraju biti ispunjeni kako bi se omogućio nesmetan psihofizički razvoj učenika tijekom školovanja, »dok njihov izostanak često dovodi do razvoja sekundarnih teškoća (npr. emotivnih teškoća, teškoća u učenju, problema u ponašanju), koje mogu dovesti i do prekida obrazovanja u adolescentnoj dobi« (Popović, Buljevac, 2016, 466). 
Tablica 2. Ukupan broj učenika u srednjim školama i učenika s teškoćama u razvoju u razdoblju od školske godine 2011./2012. do 2018./2019.

\begin{tabular}{|c|c|c|}
\hline Školska godina & Ukupan broj učenika & $\begin{array}{c}\text { Ukupan broj učenika s } \\
\text { teškoćama u razvoju }\end{array}$ \\
\hline $2011 . / 2012$. & 183807 & 1779 \\
\hline $2012 . / 2013$. & 184793 & 2056 \\
\hline $2013 . / 2014$. & 182878 & 2568 \\
\hline $2014 . / 2015$. & 178661 & 3375 \\
\hline $2015 . / 2016$. & 170661 & 4099 \\
\hline $2016 . / 2017$. & 162556 & 4901 \\
\hline $2017 . / 2018$. & 155642 & 5500 \\
\hline $2018 . / 2019$. & 148466 & 5626 \\
\hline
\end{tabular}

Izvor: Državni zavod za statistiku, 2020a, 2020b, 2019a, 2019b, 2018a, 2018b, 2017a, 2017b, 2016a, 2016b, 2015a, 2015b, 2014a, 2014b, 2013a, $2013 b$

\section{Metodologija}

Cilj ovog istraživanja bio je ispitati stavove nastavnika geografije osnovnih i srednjih škola o radu s djecom s teškoćama u razvoju u nastavi geografije. Hipoteze su bile da su nastavnici geografije kvalificirani za rad s učenicima s teškoćama u razvoju, da su spremni sudjelovati na edukacijama o poučavanju učenika s teškoćama u razvoju te da u svome radu prilagođavaju nastavne metode učenicima s teškoćama u razvoju. U skladu s rezultatima već provedenih istraživanja o radu s djecom s teškoćama (Ljubić, Kiš Glavaš, 2003; Resnik Planinc, Kolnik, 2016) postavljena je i hipoteza da postoje razlike u stavovima nastavnika geografije koji rade u osnovnim i srednjim školama. Za potrebe istraživanja provedeno je anketno ispitivanje kako bi se utvrdili stavovi, iskustva i mišljenja o radu s učenicima s teškoćama u nastavi geografije. Anketni 
upitnik sastavljen je po uzoru na upitnik mišljenja o integraciji (MOI) (Kiš-Glavaš, Fulgosi-Masnjak, 2002; Ljubić, Kiš-Glavaš, 2003) kojim su ispitani stavovi nastavnika o edukacijskoj integraciji te anketni upitnik Nikčević-Milković et al. (2016) kojim su se ispitivale obrazovne potrebe darovitih učenika koji slično kao i učenici s teškoćama nailaze na specifične probleme tijekom školovanja. Pitanja i tvrdnje prilagođeni su temi istraživanja te specifičnostima geografije kao nastavnoga predmeta u osnovnoj i srednjoj školi. Istraživanje je provedeno online, putem društvene mreže Facebook, u razdoblju od studenog do prosinca 2018. U istraživanju je sudjelovalo 110 ispitanika. Uzorak je nasumično odabran i sudjelovali su nastavnici s područja cijele Hrvatske. Anketno ispitivanje provedeno je u sklopu diplomskoga rada Dominka Svilana Rad s učenicima s teškoćama u razvoju u nastavi geografije (2019).

Anketni upitnik sastojao se od tvrdnji čijom su analizom utvrđeni stavovi nastavnika geografije o radu s učenicima s teškoćama u razvoju. Uvodni dio upitnika odnosio se na osnovne sociodemografske podatke o ispitanicima. Anketu je ispunilo 74,3 \% žena i 25,7 \% muškaraca. Od ukupnog broja ispitanika, najviše ih je u zvanju profesora (nastavnika) $\mathrm{i}$ to $65,5 \%$, slijedi $14,5 \%$ mentora, $14,5 \%$ nastavnika pripravnika i $6,5 \%$ savjetnika. Pomoćnici u nastavi nisu sudjelovali u istraživanju. Prema duljini radnog staža u osnovnim i srednjim školama, 40,9 \% ispitanika radi u školi od 5 do 15 godina, 39,1 \% ispitanika manje od 5 godina, 11,8 \% ispitanika od 16 do 25 godina, 8,2 \% ispitanika od 26 do 35 godina. Niti jedan od ispitanika u školi ne radi dulje od 36 godina. Najveći udio ispitanika zaposlen je u školi manje od 15 godina ( $80 \%$ ). Jedan od razloga zašto je najveći udio ispitanika zaposlenih do 15 godina u školstvu ispunio ovaj anketni upitnik je činjenica da je istraživanje provedeno online putem društvenih mreža, a upravo se mlađa populacija više koristi društvenim mrežama. Drugi dio upitnika čine tri subskale koje se odnose na: osobne stavove i iskustva nastavnika u radu s učenicima s teškoćama u razvoju, zatim mogućnosti učenika s teškoćama za sudjelovanje u nastavnim aktivnostima, u svakodnevnoj komunikaciji i suradnji s drugim učenicima te njihovu motiviranost za učenje, a trećom subskalom ispitani su stavovi nastavnika geografije o primjeni nastavnih metoda u radu s učenicima ovisno o teškoći. Kod svake od spomenutih tvrdnji ispitanici su odredili u kojoj mjeri se slažu na 5-stupanjskoj Likertovoj skali, s vrijednostima od 1 - uopće se ne slažem, do 5 - u 
potpunosti se slažem. Posljednji dio upitnika bila su pitanja otvorenog tipa gdje su ispitanici naveli probleme u radu i prijedloge za poboljšanja u radu s učenicima s teškoćama. S obzirom na podatke koji su dobiveni anketnim istraživanjem, a izraženi su na ordinalnoj ljestvici, korišten je Mann-Whitneyjev (U) test da bi se ispitalo postoje li razlike u stavovima između nastavnika koji rade u osnovnim i srednjim školama. U analizi je korišten računalni program Statistica 13.5.

\section{Rezultati i rasprava}

Prva subskala u upitniku odnosi se na stavove nastavnika o vlastitoj spremnosti i educiranosti za rad s djecom s teškoćama (Tablica 3). Rezultati istraživanja pokazuju da su nastavnici geografije podijeljenih stavova o radu s djecom s teškoćama. Naime, gotovo polovica nastavnika nerado u svom razredu radi s djecom s teškoćama. Moguće je da je jedan od razloga za takav stav nedovoljno poznavanje nastavnih metoda prilagođenih djeci s teškoćama u razvoju. Budući da su u istraživanju sudjelovali nastavnici osnovnih i srednjih škola, analizirane su moguće razlike u njihovim stavovima. Neka dosadašnja istraživanja s područja obrazovne inkluzije pokazala su da postoji značajna razlika u stavovima učitelja osnovnih i nastavnika srednjih škola o obrazovnoj inkluziji učenika s posebnim potrebama u redoviti sustav odgoja i obrazovanja (Schumm, Vaughn, 1992; Schumm et al., 1995; Ljubić, Kiš-Glavaš, 2003; Kudek Mirošević, Jurčević Lozančić, 2014; Nikčević-Milković et al., 2016). U navedenim istraživanjima pokazalo se da su nastavnici osnovnih škola spremniji prilagoditi se učenicima s teškoćama u svim fazama poučavanja, tijekom planiranja same izvedbe poučavanja te naknadnog vrednovanja.

$\mathrm{U}$ ovom istraživanju sudjelovao je veći broj nastavnika geografije koji rade u osnovnim školama u odnosu na nastavnike srednjih škola. Razlog tome je satnica geografije koja je znatno veća u osnovnim nego u srednjim školama. Rezultati ovog istraživanja pokazuju da su nastavnici geografije u osnovnim školama manje skloni radu s učenicima s teškoćama u razvoju. Jedan od mogućih razloga je taj što se nastavnici u osnovnim školama susreću s većim brojem učenika s teškoćama i samim time s većim spektrom teškoća: od teškoća koje u radu zahtijevaju minimalne prilagodbe do onih koje u radu nastavnika zahtijevaju 
znatne prilagodbe, kako nastavnih strategija, postupaka i metoda, tako i nastavnih pomagala i sredstava (Resnik Planinc, Kolnik, 2016).

Tablica 3. Vrijednosti Mann-Whitneyjeva testa s obzirom na razlike u stavovima nastavnika geografije u osnovnim i srednjim školama o radu $\mathrm{s}$ učenicima s teškoćama u razvoju na nastavi geografije

\begin{tabular}{|c|c|c|c|}
\hline Tvrdnja/čestica & $\overrightarrow{\underline{s}}$ & 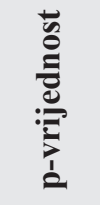 & 丞 \\
\hline $\begin{array}{l}\text { Rado bih u svom razredu radio/la s učenikom s } \\
\text { teškoćama u razvoju. }\end{array}$ & $-2,13^{*}$ & 0,033 & 2,57 \\
\hline $\begin{array}{l}\text { Spreman/na sam surađivati s roditeljima učenika s } \\
\text { teškoćama u razvoju }\end{array}$ & $-0,62$ & 0,538 & 4,40 \\
\hline $\begin{array}{l}\text { Dovoljno sam educiran/a za rad s učenicima s } \\
\text { teškoćama u razvoju. }\end{array}$ & $-2,30^{*}$ & 0,022 & 2,44 \\
\hline $\begin{array}{l}\text { Spreman/na sam surađivati sa stručnim službama } \\
\text { kako bih se pridonijelo razvoju učenika s } \\
\text { teškoćama u razvoju. }\end{array}$ & $-0,48$ & 0,630 & 4,40 \\
\hline $\begin{array}{l}\text { Spreman/na sam ići na daljnje usavršavanje } \\
\text { (seminari tečajevi,...) kako bih usavršio/la } \\
\text { metode rada s učenikom s teškoćama u razvoju. }\end{array}$ & $-1,23$ & 0,218 & 4,08 \\
\hline $\begin{array}{l}\text { Spreman/na sam osigurati roditeljima djece s } \\
\text { teškoćama u razvoju dovoljno informacija i } \\
\text { savjeta o eventualnim teškoćama koje njihovo } \\
\text { dijete ima u okviru nastave geografije. }\end{array}$ & $-0,88$ & 0,377 & 4,32 \\
\hline $\begin{array}{l}\text { Spreman/na sam prilagođavati materijale iz } \\
\text { nastave geografije učenicima s teškoćama u } \\
\text { razvoju. }\end{array}$ & $-0,33$ & 0,744 & 4,25 \\
\hline $\begin{array}{l}\text { Spreman/na sam koristiti svoje slobodno vrijeme } \\
\text { za organizaciju dodatnih materijala iz geografije } \\
\text { za učenike s teškoćama u razvoju. }\end{array}$ & $-2,09$ & 0,037 & 3,16 \\
\hline $\begin{array}{l}\text { Sposoban/na sam stvoriti pozitivno ozračje u } \\
\text { razredu kako bi drugi učenici prihvatili dijete s } \\
\text { teškoćama u razvoju }\end{array}$ & $-0,02$ & 0,983 & 4,31 \\
\hline
\end{tabular}




\begin{tabular}{|l|c|c|c|}
\hline $\begin{array}{l}\text { Kurikulum omogućuje dovoljno vremena i } \\
\text { prostora za individualizaciju nastave. }\end{array}$ & $-2,03^{*}$ & 0,042 & 1,55 \\
\hline $\begin{array}{l}\text { Inkluzija zahtijeva puno veću odgovornost } \\
\text { stručnih suradnika prema učenicima s teškoćama } \\
\text { u razvoju i njegovim roditeljima. }\end{array}$ & $-0,01$ & 0,991 & 4,37 \\
\hline $\begin{array}{l}\text { Redoviti program uz prilagodbu sadržaja i } \\
\text { individualizirane postupke je optimalni pristup za } \\
\text { rad s učenicima s teškoćama u razvoju. }\end{array}$ & $-1,95$ & 0,051 & 4,2 \\
\hline
\end{tabular}

${ }^{*} \mathrm{p}<0,05$

Za uspješnu provedbu inkluzivnog obrazovanja u svakodnevnoj školskoj praksi važna su temeljna znanja o odgoju i obrazovanju djece s teškoćama u razvoju. Ovo istraživanje, slično kao i brojna dosadašnja (Dingle et al., 2004; Kudek Mirošević, Jurčević Lozančić, 2014; Richard, Clough, 2004 u: Bouillet, Bukvić, 2015; Phillips, Cranby, 2015), pokazalo je da se nastavnici ne osjećaju dovoljno kompetentnima za inkluzivnu praksu. Ipak, postoji razlika u stavovima o kompetentnosti za rad s djecom s teškoćama u razvoju. Nastavnici geografije koji rade u srednjim školama smatraju se kompetentnima za razliku od nastavnika u osnovnim školama. Da bi znali kako poučavati učenike s teškoćama u razvoju, nastavnici moraju imati adekvatnu metodičku izobrazbu koja podrazumijeva prilagodbe odgojno-obrazovnih ishoda i razine njihove ostvarenosti. Pozitivni pomaci u obrazovanju (budućih) nastavnika geografije vidljivi su posljednjih godina jer je primjerice na Odjelu za geografiju u Zadru uveden kolegij »Inkluzijski odgoj i obrazovanje«, a na Odsjeku za geografiju u Zagrebu studenti na nastavničkom studiju geografije slušaju kolegij »Metodika rada s učenicima s posebnim potrebama«. Uz navedeno, dio vještina i znanja za rad s učenicima s teškoćama u razvoju studenti će usvojiti na kolegijima poput »Metodike nastave geografije « (I, II i III). S obzirom da je dio navedenih kolegija uveden tijekom posljednjih deset godina, najveći dio ispitanika tijekom studija nije stekao potrebna znanja i kompetencije koje bi ih pripremile i obrazovale za inkluzivnu praksu. Da bi nastavnici uspješno i na adekvatan način poučavali sve učenike potrebno je stalno obogaćivati studijske programe i uvoditi kolegije koji će im pružiti nova znanja i razvijati vještine potrebne za rad s djecom s teškoćama. Nastavnici geografije koji se ne osjećaju dovoljno kompetentnima smatraju da im je potreb- 
no dodatno obrazovanje da bi uspješno poučavali djecu s teškoćama. Ohrabrujuće je da su gotovo svi nastavnici, u cilju postizanja znanja i vještina za rad s djecom s teškoćama, spremni za daljnja usavršavanja čime se potvrđuje značaj stalnog obrazovanja nastavnika. Poticaj primjene obrazovne inkluzije daje UNESCO koji naglašava tri ključna cilja obrazovne inkluzije: kvalitetno informiranje o aktivnostima vezanima za provedbu inkluzije, savjetovanje u području provedbe inkluzije te obrazovanje nastavnika (Vican, Karamatić Brčić, 2013).

Važan uvjet uspješnosti provedbe inkluzivnog obrazovanja je suradnja nastavnika, učenika i roditelja kao i suradnja sa stručnim službama (Ljubić, Kiš-Glavaš, 2003; Resnik Planinc, Kolnik, 2016). Naime, osnovne pretpostavke inkluzije uključuju: kompetencije učitelja, suradnju sa stručno-razvojnom službom škole i suradnju s roditeljima, uključivanje pomoćnika u nastavi itd. (Nikčević-Milković et al., 2016). Nastavnici smatraju kako su im potrebne dodatne kompetencije za uspješan rad s djecom s teškoćama (Resnik Planinc, Kolnik, 2016; Karamatić Brčić, Viljac, 2018). Nastavnici geografije u Sloveniji nedostatak komunikacije s roditeljima smatraju značajnom zaprekom u radu s učenicima s teškoćama (Resnik Planinc, Kolnik, 2016). Rezultati ovog istraživanja pokazali su da su nastavnici geografije spremni za suradnju s roditeljima djece s teškoćama i za suradnju sa stručnom službom u školi te da smatraju kako je suradnja roditelja učenika s teškoćama u razvoju i predmetnog nastavnika od iznimne važnosti. Navedene tvrdnje imale su najveću razinu slaganja $(M=4,40)$. Nastavnici su spremni surađivati s roditeljima i pružiti im savjete vezane za prevladavanje teškoća koje učenik ima u nastavi geografije. Isto tako, nastavnici geografije spremni su surađivati sa stručnim službama. Istraživanje provedeno među učiteljima i nastavnicima u Ličko-senjskoj županiji pokazuje da učitelji i nastavnici smatraju da su suradnja sa stručno-razvojnom službom škole i podrška škole u radu s učenicima s posebnim potrebama ključne za kompetentan odgojno-obrazovni rad (Nikčević-Milković et al., 2016).

»Provođenje inkluzivnog odgoja i obrazovanja u školi zahtijeva jedan novi kurikulski pristup usmjeren na novije metode, nove kompetencije koje su u skladu za zahtjevima suvremenih obrazovnih reformi.« (Karamatić Brčić, Viljac, 2019, 96) 
Kako bi bili uspješni u poučavanju, a učenici s teškoćama mogli pratiti nastavu i usvajati potrebna znanja te razvijati potrebne vještine, nastavnici geografije spremni su prilagođavati nastavne sadržaje i materijale, imajući na umu učenikove potrebe. Pojedini nastavnici geografije prilagođavaju postojeće nastavne sadržaje, dok je dio nastavnika spreman više vremena posvetiti izradi dodatnih materijala. Individualizirani pristup svakom učeniku podrazumijeva posebno prilagođeni odgojno-obrazovni program, odnosno program u kojemu se unutar posebno određenih nastavnih tema primjenjuju strategije podrške ovisno o teškoćama. Istraživanje pokazuje da većina nastavnika smatra kako im postojeći kurikulum ne ostavlja dovoljno vremena za individualizaciju nastave. Navedena tvrdnja imala je najmanju razinu slaganja $u$ upitniku (M=1,55). Premda su nastavnici spremni pomoći učenicima s teškoćama tijekom pisanja testa ili rada na zadatku, u manjoj su mjeri spremni prilagoditi kurikulum ili sastavljati poseban test prilagođen ishodima koje učenik s teškoćama može usvojiti (Schumm, Vaughn, 1992; Schumm et al., 1995).

Prema prijedlogu Okvira za poticanje i prilagodbu iskustava učenja te vrednovanje postignuća djece i učenika s teškoćama (MZOS, 2016) inkluzija znači stvaranje okruženja u kojemu učenici s teškoćama u razvoju imaju priliku razviti svoj maksimalni potencijal. Nastavnici geografije smatraju da su sposobni razvijati pozitivno ozračje u razredu kako bi učenici s teškoćama bili prihvaćeni od strane ostalih učenika. Pozitivno ozračje u razredu od velikog je značaja za učenike s teškoćama u razvoju jer im nije dovoljna samo prilagodba nastavnog procesa nego im je potrebno i prihvaćanje, stalno ohrabrivanje i poticanje što može pozitivno utjecati na njihovu motiviranost.

Drugom subskalom anketnog upitnika cilj je bio doznati kako nastavnici geografije percipiraju mogućnosti učenika s teškoćama za sudjelovanje u nastavnim aktivnostima, sudjelovanje u svakodnevnoj komunikaciji i suradnji s drugim učenicima te njihovu motiviranost za učenje (Tablica 4). U redovni proces obrazovanja uključuju se oni učenici koji su prema procjeni stručnih službi u mogućnosti pohađati redovnu nastavu (Pravilnik o postupku utvrđivanja psihofizičkog stanja djeteta, učenika te sastavu stručnih povjerenstava, NN 67/2014). Nastavnici geografije smatraju da učenici s teškoćama u razvoju mogu sudjelovati u većini aktivnosti u redovnoj nastavi. Istovremeno, suglasni 
su da učenicima s teškoćama u razvoju treba više vremena u rješavanju pojedinih zadataka. U geografiji to se posebice odnosi na zadatke iz domene kartografske pismenosti.

Tablica 4. Vrijednosti Mann-Whitneyjeva testa s obzirom na razlike u stavovima nastavnika geografije u osnovnim i srednjim školama o osobinama i potrebama učenika s teškoćama na nastavi geografije

\begin{tabular}{|c|c|c|c|}
\hline Tvrdnja/čestica & 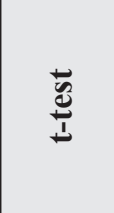 & 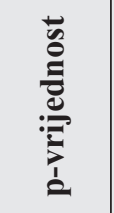 & 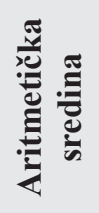 \\
\hline $\begin{array}{l}\text { Učenici s teškoćama u razvoju ne mogu pohađati } \\
\text { redovnu školu. }\end{array}$ & 0,99 & 0,325 & 2,44 \\
\hline $\begin{array}{l}\text { Učenici s teškoćama u razvoju ne mogu } \\
\text { sudjelovati u većini aktivnosti u redovnoj školi. }\end{array}$ & 1,18 & 0,239 & 2,68 \\
\hline $\begin{array}{l}\text { Učenici s teškoćama u razvoju razvijaju dobru } \\
\text { socijalizaciju s učenicima }\end{array}$ & $-1,16$ & 0,245 & 3,35 \\
\hline $\begin{array}{l}\text { Učenici s teškoćama u razvoju često traže pomoć } \\
\text { drugih učenika u rješavanju radnih zadataka. }\end{array}$ & $-0,78$ & 0,434 & 2,85 \\
\hline $\begin{array}{l}\text { Učenici s teškoćama u razvoju spremna su na } \\
\text { suradnju s drugim učenicima pri izvršavanju } \\
\text { zadataka. }\end{array}$ & $-0,86$ & 0,389 & 3,38 \\
\hline $\begin{array}{l}\text { Učenicima s teškoćama u razvoju treba više } \\
\text { vremena da obave svoj posao. }\end{array}$ & 0,95 & 0,341 & 4,38 \\
\hline $\begin{array}{l}\text { Učenik s teškoćama u razvoju lako sklapa } \\
\text { prijateljstva i dobre odnose s vršnjacima. }\end{array}$ & $-1,12$ & 0,263 & 2,88 \\
\hline $\begin{array}{l}\text { Svaki učenik s teškoćama u razvoju zahtijeva } \\
\text { primjenu specifičnih pomagala, sredstava i } \\
\text { opreme za ostvarivanje odgojno obrazovnih i } \\
\text { rehabilitacijskih zadataka. }\end{array}$ & $-0,63$ & 0,528 & 3,74 \\
\hline $\begin{array}{l}\text { Učenici s teškoćama u razvoju su motivirana za } \\
\text { rad. }\end{array}$ & $-2,17^{*}$ & 0,030 & 2,73 \\
\hline $\begin{array}{l}\text { Učenici s teškoćama u razvoju koncentrirana su } \\
\text { na rad. }\end{array}$ & $-1,34$ & 0,181 & 2,38 \\
\hline
\end{tabular}




\begin{tabular}{|l|c|c|c|}
\hline $\begin{array}{l}\text { Učenici s teškoćama u razvoju imaju teškoće u } \\
\text { komunikaciji s drugim učenicima. }\end{array}$ & 0,29 & 0,773 & 3,28 \\
\hline $\begin{array}{l}\text { Učenici s teškoćama u razvoju zahtijevaju } \\
\text { posebne metode rada u nastavi geografije. }\end{array}$ & 0,66 & 0,510 & 4,24 \\
\hline $\begin{array}{l}\text { Učenici s teškoćama u razvoju zahtijevaju } \\
\text { planiranje sadržaja u školi u suradnji s } \\
\text { roditeljima, učenikom i stručnim suradnicima. }\end{array}$ & 0,01 & 0,991 & 4,20 \\
\hline $\begin{array}{l}\text { Učenici s teškoćama u razvoju zahtijevaju } \\
\text { posebne udžbenike prilagođene specifičnom } \\
\text { poremećaju. }\end{array}$ & $2,74^{*}$ & 0,006 & 4,12 \\
\hline $\begin{array}{l}\text { Pomoćnik u nastavi potreban je svakom učeniku s } \\
\text { teškoćama u razvoju. }\end{array}$ & $-0,97$ & 0,333 & 3,37 \\
\hline
\end{tabular}

${ }^{*} \mathrm{p}<0,05$

U Okviru za poticanje i prilagodbu iskustava učenja te vrednovanje postignuća djece i učenika s teškoćama (MZOS, 2016) navodi se da je za većinu teškoća djeci potrebno omogućiti više vremena za obavljanje zadataka. Uz dodatno vrijeme, učenicima s teškoćama potrebna su specifična pomagala i oprema. Nastavnici geografije smatraju da svako dijete s teškoćama u razvoju zahtijeva primjenu specifičnih nastavnih pomagala, sredstava i opreme. Pri tome treba uzeti u obzir široki spektar teškoća, ali i činjenicu da nabava posebne opreme zahtjeva znatna financijska sredstva. Svaka teškoća zahtijeva posebne prilagodbe nastave u smislu primjene određenih strategija poučavanja, metoda rada i postupaka. Pri odabiru pojedinih strategija nastavnici se rukovode različitim kriterijima, a među najvažnijim su odgojno-obrazovni ishodi, iskustva učenika, predznanja, interesi i psihofizičke sposobnosti učenika (Kostović-Vranješ, 2015, 117). Samo pojedini nastavnici smatraju da ne mogu ili ne trebaju prilagoditi proces poučavanja djeci s teškoćama. Značajna pomoć svim nastavnicima su mišljenja stručnog povjerenstva koja, prema vrsti i stupnju teškoća u razvoju pojedinog djeteta, određuju koje su metode i pomagala najprimjerenija za rad s pojedinim učenikom. Prema Borić i Tomić $(2012,14)$ svaki oblik teškoća u razvoju zahtjeva »primjenu posebnih odgojno-obrazovnih i rehabilitacijskih postupaka, specifičnih pomagala, sredstava i opreme te osposobljeno i educirano rehabilitacijsko osoblje«. Udžbenici su također važni za svakodnevni rad s učenicima s teškoćama. Međutim, ne postoje udžbenici 
za sve oblike teškoća i poremećaja. Neki su udžbenici za nastavu geografije ipak prilagođeni i dostupni kao što su Priča o Zemlji (Borko, Štancl, 2019), Put oko svijeta (Borko, Štancl, 2019). Rezultati ovog istraživanja pokazuju da veću važnost i potrebu za udžbenicima koji su prilagođeni djeci s teškoćama u razvoju izražavaju nastavnici koji rade u osnovnim školama.

Nastavnici se u radu susreću i s pitanjem motivacije učenika. Prema kurikulumu za predmet Geografija uloga nastavnika je kreativnim planiranjem u poučavanju i primjenom odgovarajućih strategija poučavanja učeniku omogućiti zanimljivu nastavu te učenicima pružiti emocionalnu, socijalnu i intelektualnu podršku (Odluka o donošenju kurikuluma za nastavni predmet Geografije za osnovne škole i gimnazije u Republici Hrvatskoj, 2019). Prema istraživanju Ristić Dedić i Jokić (2014), osnovna motivacija za učenje i rad učenika vođena je željom za postizanjem što većih ocjena. Ocjene su te na osnovu kojih učenici u redovnoj nastavi upisuju srednju školu prema vlastitom izboru. Učenici s teškoćama u razvoju upisuju se u srednju školu temeljem Pravilnika o elementima $i$ kriterijima za izbor kandidata za upis u I. razred srednje škole (NN 49/2015) kojim se vrednuje postignuti uspjeh, »na zasebnim ljestvicama poretka, a temeljem ostvarenog ukupnog broja bodova utvrđenog tijekom postupka vrednovanja, u programima obrazovanja za koje posjeduju stručno mišljenje službe za profesionalno usmjeravanje Hrvatskoga zavoda za zapošljavanje« (članak 23/2). Znatan dio nastavnika geografije smatra da učenici s teškoćama nisu motivirani za rad tijekom nastave. Rezultati istraživanja pokazuju da postoji statistički značajna razlika u stavovima o motiviranosti učenika s teškoćama. Nastavnici u srednjim školama uglavnom se slažu s navedenom tvrdnjom, dok se većina nastavnika u osnovnim školama ne slaže s navedenom tvrdnjom.

»Inkluzivno obrazovanje usmjereno je na poticanje razvoja svijesti kod učenika i školskog osoblja o važnosti inkluzije u cilju prihvaćanja različitosti kao poticaja u učenju.« (Vican, Karamatić Brčić, 2019, 55)

U školskom okruženju važan je osjećaj prihvaćenosti i pripadnosti, suradnja između učenika i uključenost svih učenika u odgojno-obrazovne aktivnosti škole. Premda ne smatraju da učenici s teškoćama lako sklapaju prijateljstva s vršnjacima, istraživanje pokazuje da nastavnici geografije tu učeničku populaciju percipiraju kao kooperativnu, spre- 
mnu na suradnju s drugim učenicima pri izvršavanju školskih zadataka što je bitan element u procesu socijalizacije.

Pomoćnici u nastavi za djecu s teškoćama na svim razinama obrazovanja prepoznati su kao važan čimbenik uspješnog odgojno-obrazovnog procesa pa je njihov dosadašnji rad uvelike pomogao djeci s teškoćama, učiteljima i nastavnicima. Oni tako predstavljaju važan čimbenik za odgojno-obrazovno uključivanje (Drandić, 2017). Zadatak pomoćnika u nastavi nije olakšavanje nastavnog procesa, nego je njihova uloga omogućavanje nastavnog procesa za dijete kojemu je potreban asistent (Greenspan, Wieder, 2003). Pravilnik o pomoćnicima u nastavi i stručnim komunikacijskim posrednicima (NN 102/2018.) definira uvođenje pomoćnika u nastavi kao oblik prilagodbe u skladu s individualnim potrebama učenika, a s ciljem izjednačavanja mogućnosti svih učenika. Pomoćnici u nastavi u okviru redovnog školskog sustava doprinose razvoju inkluzije jer učenicima omogućuju individualni pristup u procesu učenja i stjecanja znanja (Karamatić Brčić, Viljac, 2018). Pomoćnici u nastavi svoju ulogu vide kao »regulacijsku i kompenzacijsku, a manje se vide kao medijatori između učenika i njegova neposrednog okruženja« (Velki, Romstein, 2015). Rezultati ovog istraživanja pokazuju da gotovo polovica ispitanih nastavnika geografije smatra da su pomoćnici u nastavi potrebni svakom učeniku s teškoćama.

S obzirom na karakteristike i potrebe djece s teškoćama, trećom subskalom ispitani su stavovi nastavnika geografije o primjeni pojedinih nastavnih metoda za različite teškoće učenika (Tablica 5). Nastavnici smatraju da tijekom rada s učenicima s teškoćama treba prilagoditi pojedine sadržaje i individualizirane postupke što poboljšava pristup u radu s učenicima s teškoćama. Svakodnevno je potrebno primjenjivati različite nastavne strategije, metode i postupke rada, kao i posebno prilagođene nastavne materijale ovisno o vrsti teškoće. 
Tablica 5. Vrijednosti Mann-Whitneyjeva testa s obzirom na razlike u stavovima nastavnika geografije u osnovnim i srednjim školama o primjeni pojedinih nastavnih sredstava i metoda te načinu poučavanja učenika s teškoćama u razvoju

\begin{tabular}{|c|c|c|c|}
\hline Tvrdnja/čestica & 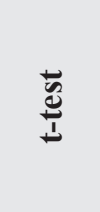 & 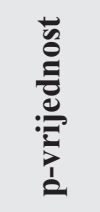 & 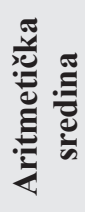 \\
\hline $\begin{array}{l}\text { Poznavanje specifičnosti poremećaja vida kod } \\
\text { učenika važno je za oblikovanje kvalitetne } \\
\text { nastave geografije. }\end{array}$ & 1,79 & 0,073 & 4,60 \\
\hline $\begin{array}{l}\text { Učenici sa specifičnim teškoćama učenja } \\
\text { zahtijevaju prilagođene nastavne materijale za } \\
\text { nastavu geografije. }\end{array}$ & 0,19 & 0,847 & 4,30 \\
\hline $\begin{array}{l}\text { Nastavni materijali iz nastave geografije trebaju } \\
\text { biti prilagođeni učenicima s disleksijom, } \\
\text { diskalkulijom i dispraksijom. }\end{array}$ & $-0,46$ & 0,645 & 4,33 \\
\hline $\begin{array}{l}\text { Učenici s poremećajima iz spektra autizma } \\
\text { ne mogu sudjelovati u nastavi geografije bez } \\
\text { asistenta u nastavi. }\end{array}$ & 1,57 & 0,115 & 4,06 \\
\hline $\begin{array}{l}\text { Učenici s visoko funkcionirajućim autizmom } \\
\text { (Aspergerovim poremećajem) mogu samostalno } \\
\text { sudjelovati u nastavi geografije. }\end{array}$ & $-0,99$ & 0,324 & 2,89 \\
\hline $\begin{array}{l}\text { Učenici s motoričkim poremećajima i kroničnim } \\
\text { bolestima zahtijevaju posebne nastavne materijale } \\
\text { za nastavu geografije. }\end{array}$ & $-0,34$ & 0,732 & 3,66 \\
\hline $\begin{array}{l}\text { Učenici s poremećajima glasovno-jezično- } \\
\text { govorne komunikacije zahtijevaju posebne } \\
\text { nastavne materijale za nastavu geografije. }\end{array}$ & $-0,62$ & 0,534 & 3,92 \\
\hline $\begin{array}{l}\text { Vizualne metode u nastavi geografije nedovoljne } \\
\text { su za učenike s oštećenjem sluha. }\end{array}$ & $-1,52$ & 0,130 & 3,60 \\
\hline $\begin{array}{l}\text { Poznavanje specifičnosti poremećaja sluha } \\
\text { kod učenika važno je za oblikovanje kvalitetne } \\
\text { nastave geografije. }\end{array}$ & 0,11 & 0,914 & 4,33 \\
\hline $\begin{array}{l}\text { Verbalne metode u nastavi geografije nedovoljne } \\
\text { su za učenike s oštećenjem vida. }\end{array}$ & $-1,46$ & 0,145 & 3,98 \\
\hline
\end{tabular}


Stavovi nastavnika geografije iz treće subskale uglavnom su ujednačeni te nema statistički značajnih razlika u stavovima nastavnika u osnovnim i srednjim školama. Nastavnici su svjesni nužnosti poznavanja pojedinih teškoća učenika pa izražavaju potrebu korištenja posebnih nastavnih materijala, postupaka, metoda i strategija za svaku pojedinu teškoću što je važno za kvalitetno oblikovanje nastave geografije. Osim toga, nastavnici smatraju da je učenicima s poremećajima iz spektra autizma nužno potreban pomoćnik u nastavi, dok za neke druge, kao npr. učenike s Aspergerovim poremećajem, dio nastavnika smatra da mogu samostalno sudjelovati u nastavi geografije.

Zadnji dio upitnika sastojao se od otvorenih pitanja koja su bila usmjerena na stavove nastavnika geografije o najčešćim problemima $\mathrm{u}$ radu $\mathrm{s}$ učenicima $\mathrm{s}$ teškoćama $\mathrm{s}$ kojima se susreću i preporukama za poboljšanje rada $\mathrm{s}$ djecom $\mathrm{s}$ teškoćama (Tablica 6). Broj učenika u razredu, financije, nedostatak pripreme, rad s učenicima koji imaju probleme s ponašanjem, ograničeno vrijeme poučavanja osnovni su čimbenici koje nastavnici navode kao prepreke na koje nailaze tijekom poučavanja učenika s teškoćama (Schumm, Vaughn, 1992). Ispitanici koji su naveli probleme u radu s djecom s teškoćama susretali su se s različitim problemima. Kao najčešći problemi izdvojeni su komunikacija $\mathrm{s}$ roditeljima $(\mathrm{f}=15)$ te općenito $\mathrm{rad} \mathrm{s}$ učenicima $\mathrm{s}$ teškoćama $(\mathrm{f}=14)$. Naglašeni su problemi u komunikaciji s roditeljima što je moguće posljedica manjkave ili nedovoljne suradnje nastavnika i roditelja. U prethodno izraženim stavovima nastavnici su potencirali važnost $i$ spremnost za suradnju s roditeljima. Poznavajući teškoće svoje djece, roditelji mogu doprinijeti kvaliteti nastavnog procesa.

Tablica 6. Problemi nastavnika geografije u radu s učenicima s teškoćama u razvoju

\begin{tabular}{|l|c|c|}
\hline \multicolumn{1}{|c|}{ Problemi } & Frekvencija & \% \\
\hline $\begin{array}{l}\text { Problemi nastali u suradnji/komunikaciji s } \\
\text { roditeljima }\end{array}$ & 15 & 25,9 \\
\hline $\begin{array}{l}\text { Problemi u radu s učenicima s teškoćama u } \\
\text { razvoju }\end{array}$ & 14 & 24,1 \\
\hline Problemi vezani uz kurikulum & 9 & 15,5 \\
\hline
\end{tabular}




\begin{tabular}{|l|c|c|}
\hline $\begin{array}{l}\text { Nedostatak pomoći od strane stručnih } \\
\text { suradnika }\end{array}$ & 4 & 6,9 \\
\hline $\begin{array}{l}\text { Nedovoljno vremena predviđeno za rad s } \\
\text { učenicima s teškoćama u razvoju }\end{array}$ & 3 & 5,2 \\
\hline $\begin{array}{l}\text { Nedovoljna edukacija za rad s učenicima s } \\
\text { teškoćama u razvoju }\end{array}$ & 3 & 5,2 \\
\hline Ostalo & 10 & 17,2 \\
\hline Ukupno & 58 & 100 \\
\hline
\end{tabular}

Nastavnici još ističu i probleme koji su vezani uz kurikulum ( $\mathrm{f}=9$ ) o čemu su prethodno izjavili da im kurikulum ne ostavlja vremena za dodatni rad s djecom s teškoćama. Frekvencija izjava nastavnika da problem predstavlja vrijeme predviđeno za rad s djecom s teškoćama ili da je problem nedovoljna osposobljenost u suprotnosti je s prethodno izraženim stavovima nastavnika gdje su ovi problemi istaknuti. Treba napomenuti da je na ovo otvoreno pitanje o problemima u radu s učenicima s teškoćama odgovorilo samo nešto više od polovice od ukupnog broja ispitanika (52,72\%). Nastavnici geografije navode i nedostatnu pomoć stručnih suradnika u školi. Pojedinim nastavnicima nedostaje pomoć stručnih suradnika koja je nužna s obzirom da se ne osjećaju dovoljno kompetentnima za rad s djecom s teškoćama. Već je prethodno rečeno da je jedan od važnih preduvjeta za uspjeh inkluzije u školama povezanost i suradnja nastavnika, stručnih suradnika i roditelja. U osnovnim školama timove stručnih suradnika najčešće čine pedagog, psiholog i stručnjak edukacijsko-rehabilitacijskog profila (edukacijski rehabilitator, logoped ili socijalni pedagog), dok u srednjim školama stručnu služnu najčešće čini samo pedagog ili psiholog.

S obzirom na navedene probleme u svakodnevnom radu, nastavnici su naveli preporuke koje se odnose na mogućnosti poboljšanja u radu $\mathrm{s}$ učenicima s teškoćama (Tablica 7). Premda je samo dio nastavnika iznio svoje preporuke $(62,72 \%$ ispitanika), najčešće se navodi organiziranje dopunske nastave $(\mathrm{f}=19)$ te individualizirani pristup i individualne konzultacije za djecu s teškoćama $(\mathrm{f}=19)$. Dopunsku nastavu škole organiziraju za učenike koji nisu savladali dijelove nastavnog gradiva, koji imaju manjkavo predznanje ili za učenike s teškoćama, a organizira se kroz cijelu nastavnu godinu što predstavlja značajnu i kontinuiranu 
pomoć učenicima, ali i nastavnicima. Dio nastavnika u cilju poboljšanja rada s djecom s teškoćama preporučuje upotrebu posebnih didaktičkih materijala, kao što su radni listići i udžbenici prilagođeni djeci s teškoćama u razvoju ( $\mathrm{f}=16)$. Nastavnici su najmanje skloni reduciranju postojećih sadržaja unutar kurikuluma $(\mathrm{f}=5)$. Premda su prethodno istaknuli nedostatak vremena u radu s djecom s teškoćama s obzirom na postojeći kurikulum, dio nastavnika nije sklon reduciranju sadržaja iz nastavnog predmeta geografije. Ovakav stav nastavnika je očekivan s obzirom da individualizacija nastave podrazumijeva izdvajanje najvažnijih ishoda poučavanja u skladu sa sposobnostima učenika te kreiranje strategija učenja i poučavanja. Nije potrebno smanjivati obujam propisanih sadržaja, već treba prilagoditi postupke tijekom procesa poučavanja i posebice vrednovanja naučenog (Milić, 2018). Pojedini nastavnici geografije rješenje za poboljšanje rada s djecom s teškoćama vide u još većem angažiranju pomoćnika u nastavi $(\mathrm{f}=10)$.

Tablica 7. Preporuke nastavnika geografije za poboljšanje pristupa u radu s učenicima s teškoćama u razvoju

\begin{tabular}{|l|c|c|}
\hline \multicolumn{1}{|c|}{ Preporuke } & Frekvencija & \% \\
\hline Dopunska nastava & 19 & 27,5 \\
\hline Individualizirani pristup & 19 & 27,5 \\
\hline Posebni materijali & 16 & 23,2 \\
\hline Pomoćnik u nastavi & 10 & 14,5 \\
\hline Reduciranje postojećih sadržaja & 5 & 7,3 \\
\hline Ukupno & 69 & 100 \\
\hline
\end{tabular}

\section{Zaključak}

Uspjeh provedbe inkluzivnog odgoja i obrazovanja uvelike ovisi o nastavnicima. Kako bi bili uspješni u radu s djecom s teškoćama važno je da tijekom studija steknu temeljna znanja i kompetencije za rad s djecom s teškoćama na svim razinama odgojno-obrazovne prakse. Zbog svojih tjelesnih, mentalnih, intelektualnih, osjetilnih oštećenja učenici 
s teškoćama nisu u mogućnosti savladati sve zadatke koji se pred njih stavljaju tijekom procesa učenja. Široki spektar poteškoća uz nedostatak materijalnih sredstava - pomagala u nastavi, metodičkih znanja i predmetno specifičnih priručnika za rad s učenicima s teškoćama u razvoju - znatno otežavaju proces obrazovanja učenika s teškoćama.

Premda je u istraživanju sudjelovalo 110 nastavnika geografije zaposlenih u osnovnim i/ili srednjim školama u Republici Hrvatskoj, niz je ograničenja koja mogu utjecati na rezultate. Od ukupnog broja anketiranih trećina radi u osnovnoj školi, dok su ostali zaposleni u gimnazijama te u najmanjoj mjeri u srednjim strukovnim školama. Razlog tome je činjenica da se geografija u osnovnim školama poučava sve četiri godine, od petog do osmog razreda, dok u srednjim školama satnica geografije varira ovisno o kurikulumu. Analizom odgovora razvidno je da većina ispitanika poučava djecu s teškoćama prema redovitom kurikulumu uz individualizaciju ili prilagođenom kurikulumu sa smanjenim opsegom nastavnih sadržaja, međutim potrebna su daljnja ispitivanja koja bi utvrdila koji oblik prilagodbe nastavnici koriste imajući na umu točno određenu poteškoću i vrstu kurikuluma koji primjenjuju.

Rezultati ovog istraživanja pokazuju spremnost nastavnika za prilagodbom te za primjenu individualiziranih postupaka, metoda i strategija poučavanja. Istovremeno nastavnici izražavaju svoju nedovoljnu kompetentnost te smatraju da im je potrebno dodatno obrazovanje kako bi uspješno poučavali djecu s teškoćama. Nastavnici osnovnih škola osjećaju se manje kompetentno od nastavnika srednjih škola. Međutim, gotovo svi ispitani nastavnici, u cilju postizanja znanja i vještina za rad s djecom s teškoćama, spremni su za daljnja usavršavanja čime se potvrđuje značaj stalnog obrazovanja nastavnika. Važne čimbenike za postizanje uspjeha u procesu odgoja i obrazovanja djece s teškoćama nastavnici vide i u tješnjoj suradnji s roditeljima i stručno-razvojnim službama te u većem angažmanu pomoćnika u nastavi. Nadalje, nastavnici procjenjuju da su učenici s teškoćama prihvaćeni među svojim vršnjacima i da su spremni na suradnju s drugim učenicima. Kada je riječ o motiviranosti učenika s teškoćama za učenje i rad u školi, rezultati istraživanja pokazuju da postoji razlika u stavovima nastavnika. Nastavnici u srednjim školama uglavnom percipiraju djecu s teškoćama motiviranima, dok se većina nastavnika u osnovnim školama ne slaže s navedenom tvrdnjom. 
Navodeći probleme u svakodnevnom radu, nastavnici izdvajaju uopće rad s djecom s teškoćama, a potom i probleme u komunikaciji s roditeljima. Preporuke koje nastavnici daju za poboljšanje u radu s djecom s teškoćama su veća zastupljenost dopunske nastave, primjena individualiziranog pristupa u nastavi i znatnije angažiranje pomoćnikâ u nastavi, a pojedini nastavnici preporučuju i izradu posebnih materijala.

Kako bi se nastavnici geografije obrazovali za rad s djecom s teškoćama potrebna su stalna usklađivanja u kurikulumima nastavničkih studija. S obzirom na izazove i probleme u primjeni obrazovne inkluzije, potrebna su i daljnja istraživanja među populacijom nastavnika geografije koja mogu biti indikator ne samo stanja nego i putokaz budućih djelovanja u cilju poboljšanja i primjene novih strategija podrške. U budućim istraživanjima trebalo bi naglasiti razliku između nastavnika koji poučavaju djecu geografiji po redovitom programu uz individualizirane postupke, redovitom programu uz prilagodbu sadržaja i individualiziranom postupku, posebnom programu uz individualizirane postupke ili posebnom programu za stjecanje kompetencija u aktivnostima svakodnevnog života rada uz individualizirane postupke što u ovom istraživanju nije učinjeno.

\section{Literatura}

Borić, Selma; Tomić, Ruža (2012), »Stavovi nastavnika osnovnih škola o inkluziji«, Metodički obzori, 7(3), str. 75-86. doi: https://doi.org/10.32728/ $\underline{\text { mo.07.3.2012.07 }}$

Borko, Lidija; Štancl, Tomislav (2016), Priča o Zemlji, radni udžbenik s CD-om iz geografije za peti razred osnovne škole za učenike s teškoćama, Zagreb: Meridijani.

Borko, Lidija; Štancl, Tomislav (2016), Put oko svijeta, radni udžbenik s CD-om iz geografije za šesti razred osnovne škole za učenike s teškoćama, Zagreb: Meridijani.

Bouillet, Deajana; Bukvić, Zlatko (2015), »Razlike u mišljenjima studenata i zaposlenih učitelja o obrazovnoj inkluziji učenika s teškoćama«, Hrvatska revija za rehabilitacijska istraživanja, 51(1), str. 9-23.

Davis, Pauline; Florian, Lani (2004), Teaching Strategies and Approaches for Pupils with Special Educational Needs: A Scoping Study, DfES Research Report RR516, Department for Education and Skills, str. 1-87. Dostupno na: https:// dera.ioe.ac.uk/6059/1/RR516.pdf [1. 12. 2020.]

Drandić, Dijana (2017), »Uloga pomoćnika u nastavi u provođenju inkluzivnog obrazovanja«, Napredak, 158(4), str. 439-459. 
[DZS] Državni zavod za statistiku (2013a), Osnovne škole i dječji vrtići i druge pravne osobe koje ostvaruju programe predškolskog odgoja, kraj šk. g. 2011./2012. i početak šk./ped. g. 2012./2013., Statistička izvješća, 1496, Zagreb: Državni zavod za statistiku, str. 1-112. Dostupno na: https://www.dzs. $\underline{\mathrm{hr} /}$ [1. 12. 2020.]

[DZS] Državni zavod za statistiku (2013b), Srednje škole i učenički domovi, kraj šk. g. 2011./2012. i početak šk. g. 2012./2013., Statistička izvješća, 1497, Zagreb: Državni zavod za statistiku, str. 1-81. Dostupno na: https://www.dzs. $\underline{\mathrm{hr} /}$ [1. 12. 2020.]

[DZS] Državni zavod za statistiku (2014a), Osnovne škole i dječji vrtići i druge pravne osobe koje ostvaruju programe predškolskog odgoja, kraj šk. g. 2012./2013. i početak šk./ped. g. 2013./2014., Statistička izvješća, 1520, Zagreb: Državni zavod za statistiku, str. 1-127. Dostupno na: https://www.dzs. $\underline{\mathrm{hr} /}[1.12 .2020$.

[DZS] Državni zavod za statistiku (2014b), Srednje škole i učenički domovi, kraj šk. g. 2012./2013. i početak šk. g. 2013./2014., Statistička izvješća, 1521, Zagreb: Državni zavod za statistiku, str. 1-91. Dostupno na: https://www.dzs. $\underline{\mathrm{hr} /}[1$. 12. 2020.]

[DZS] Državni zavod za statistiku (2015a), Osnovne škole i dječji vrtići $i$ druge pravne osobe koje ostvaruju programe predškolskog odgoja, kraj šk. g. 2013./2014. i početak šk./ped. g. 2014./2015, Statistička izvješća, 1543, Zagreb: Državni zavod za statistiku, str. 1-129. Dostupno na: https://www.dzs. $\underline{\mathrm{hr} /}$ [1. 12. 2020.]

[DZS] Državni zavod za statistiku (2015b), Srednje škole i učenički domovi, kraj šk. g. 2013./2014. i početak šk. g. 2014./2015., Statistička izvješća, 1544, Zagreb: Državni zavod za statistiku, str. 1-91. Dostupno na: https://www.dzs. $\underline{\mathrm{hr} /}[1.12 .2020$.

[DZS] Državni zavod za statistiku (2016a), Osnovne škole i dječji vrtići $i$ druge pravne osobe koje ostvaruju programe predškolskog odgoja, kraj šk. g. 2014./2015. i početak šk./ped. g. 2015./2016., Statistička izvješća, 1568, Zagreb: Državni zavod za statistiku, str. 1-127. Dostupno na: https://www.dzs. $\underline{\mathrm{hr} /}$ [1. 12. 2020.]

[DZS] Državni zavod za statistiku (2016b), Srednje škole i učenički domovi, kraj šk. g. 2014./2015. i početak šk. g. 2015./2016., Statistička izvješća, 1569, Zagreb: Državni zavod za statistiku, str. 1-95. Dostupno na: https://www.dzs. $\underline{\mathrm{hr} /}[1.12 .2020$.

[DZS] Državni zavod za statistiku (2017a), Osnovne škole i dječji vrtići i druge pravne osobe koje ostvaruju programe predškolskog odgoja, kraj šk. g. 2015./2016. i početak šk./ped. g. 2016./2017., Statistička izvješća, 1597, Zagreb: Državni zavod za statistiku, str. 1-127. Dostupno na: https://www.dzs. $\underline{\mathrm{hr} /}$ [1. 12. 2020.]

[DZS] Državni zavod za statistiku (2017b), Srednje škole i učenički domovi, kraj šk. g. 2015./2016. i početak šk. g. 2016./2017., Statistička izvješća, 1598, Zagreb: Državni zavod za statistiku, str. 1-95. Dostupno na: https://www.dzs. $\underline{\mathrm{hr} /}[1.12 .2020$. 
[DZS] Državni zavod za statistiku (2018a), Osnovne škole i dječji vrtići $i$ druge pravne osobe koje ostvaruju programe predškolskog odgoja, kraj šk. g. 2016./2017. i početak šk./ped. g. 2017./2018., Statistička izvješća, 1619, Zagreb: Državni zavod za statistiku, str. 1-127. Dostupno na: https://www.dzs. $\underline{\mathrm{hr} /}$ [1. 12. 2020.]

[DZS] Državni zavod za statistiku (2018b), Srednje škole i učenički domovi, kraj šk. g. 2016./2017. i početak šk. g. 2017./2018., Statistička izvješća, 1620, Zagreb: Državni zavod za statistiku, str. 1-95. Dostupno na: https://www.dzs. $\underline{\mathrm{hr} /}$ [1. 12. 2020.]

[DZS] Državni zavod za statistiku (2019a), Osnovne škole i dječji vrtići $i$ druge pravne osobe koje ostvaruju programe predškolskog odgoja, kraj šk. g. 2017./2018. i početak šk./ped. g. 2018./2019., Statistička izvješća, 1662, Zagreb: Državni zavod za statistiku, str. 1-127. Dostupno na: https://www.dzs. $\underline{\mathrm{hr} /}[1.12 .2020$.

[DZS] Državni zavod za statistiku (2019b), Srednje škole i učenički domovi, kraj šk. g. 2017./2018. i početak šk. g. 2018./2019., Statistička izvješća, 1643, Zagreb: Državni zavod za statistiku, str. 1-95. Dostupno na: https://www.dzs. $\underline{\mathrm{hr} /}[1$. 12. 2020.]

[DZS] Državni zavod za statistiku (2020a), Osnovne škole i dječji vrtići i druge pravne osobe koje ostvaruju programe predškolskog odgoja, kraj šk. g. 2018./2019. i početak šk./ped. g. 2019./2020., Statistička izvješća, 1663, Zagreb: Državni zavod za statistiku, str. 1-127. Dostupno na: https://www.dzs. $\underline{\mathrm{hr} /}$ [1. 12. 2020.]

[DZS] Državni zavod za statistiku (2020b), Srednje škole i učenički domovi, kraj šk. g. 2018./2019. i početak šk. g. 2019./2020., Statistička izvješća, 1664, Zagreb: Državni zavod za statistiku, str. 1-95. Dostupno na: https://www.dzs. $\underline{\mathrm{hr} /}[1$. 12. 2020.]

Greenspan, Stanley I.; Wieder, Serena (2003), Dijete s posebnim potrebama: Poticanje intelektualnog i emocionalnog razvoja, Zagreb: Ostvarenje.

Karamatić Brčić, Matilda (2012), »Implementacija i provedba inkluzivnog odgoja i obrazovanja u sustavu redovnih škola«, Magistra Iadertina, 7(1), str. 101109. doi: https://doi.org/10.15291/magistra.822

Karamatić Brčić, Matilda; Viljac, Tea (2018), »Stavovi nastavnika o inkluzivnom odgoju i obrazovanju«, Magistra Iadertina, 13(1), str. 92-104. doi: https:// doi.org/10.15291/magistra.2815

Kiš-Glavaš, Leila; Fulgosi-Masnjak, Rea (2002), Do prihvaćanja zajedno: Integracija djece s posebnim potrebama. Priručnik za učitelje, Hrvatska udruga za stručnu pomoć djeci s posebnim potrebama-IDEM, Zagreb: Impresum.

Kiš-Glavaš, Lelia; Wagner Jakab, Ana (2001), »Stavovi učitelja prema poučavanju kao determinante promjene stavova prema integraciji učenika usporenog kognitivnog razvoja«, Hrvatska revija za rehabilitacijska istraživanja, 37(2), str. 191-202.

Kostović-Vranješ, Vesna (2015), Metodika nastave predmeta prirodoslovnog područja, Zagreb: Školska knjiga. 
Kudek Mirošević, Jasna; Jurčević Lozančić, Anka (2014), »Stavovi odgojitelja i učitelja o provedbi inkluzije u redovitim predškolskim ustanovama i osnovnim školama«, Hrvatska revija za rehabilitacijska istraživanja, 50(2), str. 17-29.

Ljubić, Maja; Kiš-Glavaš, Leila (2003), »Razlike u stavovima nastavnika osnovnih i srednjih škola prema edukacijskoj integraciji«, Hrvatska revija za rehabilitacijska istraživanja, 39(2), str. 129-136.

Milić, Vesna (2018), »Procjena i planiranje primjerenih postupaka podrške učenicima s teškoćama u razvoju i poučavanju geografije«, Geografski horizont, 64(2), str. 41-59.

[MZO] Ministarstvo znanosti i obrazovanja RH (2016), Okvir za poticanje i prilagodbu iskustava učenja te vrednovanje postignuća djece i učenika s teškoća$m a$, prijedlog, Zagreb: Ministarstvo znanosti i obrazovanja RH. Dostupno na: http://www.kurikulum.hr/wp-content/uploads/2016/02/Okvir-djeca-i-ucenici-s-teskocama.pdf [1. 12. 2020.]

Nikčević-Milković Anela; Jerković Ana; Rukavina Maja (2016), »Stanje, problemi i potrebe rada s darovitim učenicima u osnovnim školama u Republici Hrvatskoj«, Magistra Iadertina, 11(1), str. 9-34. doi: https://doi.org/10.15291/ magistra. 1325

[NN] Narodne novine (2014), Pravilnik o postupku utvrđivanja psihofizičkog stanja djeteta, učenika te sastavu stručnih povjerenstava, 67/2014 (2. 6. 2014.). Dostupno na: https://narodne-novine.nn.hr/clanci/sluzbeni/2014_06_67_1279. $\underline{\mathrm{html}}$ [1. 12. 2020.]

[NN] Narodne novine (2015), Pravilnik o osnovnoškolskom i srednjoškolskom odgoju i obrazovanju učenika s teškoćama u razvoju, 24/2015 (4. 3. 2015.). Dostupno na: https://narodne-novine.nn.hr/clanci/sluzbeni/2015 $03 \quad 24 \quad 510$. html [1. 12. 2020.]

[NN] Narodne novine (2015), Pravilnik o elementima i kriterijima za izbor kandidata za upis $u$ I. razred srednje škole, 49/2015, (6. 5. 2015.). Dostupno na: https://narodne-novine.nn.hr/clanci/sluzbeni/2015 05 49 981.html [1. 12. 2020.]

[NN] Narodne novine (2018), Pravilnik o pomoćnicima u nastavi i stručnim komunikacijskim posrednicima, 102/2018 (21. 11. 2018.). Dostupno na: https:// narodne-novine.nn.hr/clanci/sluzbeni/2018_11_102_1992.html [1. 12. 2020.]

[NN] Narodne novine (2019), Odluka o donošenju kurikuluma za nastavni predmet Geografije za osnovne škole i gimnazije u Republici Hrvatskoj (22. 1. 2019.). Dostupno na: https://narodne-novine.nn.hr/clanci/sluzbeni/2019_01_7_145. $\underline{\mathrm{html}}$ [1. 12. 2020.]

Phillips, Michael Davis; Cranby, Stephen (2015), »Enhancing inclusion in Geography classrooms«, u: Deppeler, Joanne M; Loreman, Tim; Smith, Ron; Florian, Lani (ur.), Inclusive Pedagogy Across the Curriculum, Emerald Group Publishing Limited, str. 65-77. doi: https://doi.org/10.1108/S1479$\underline{363620150000007014}$ 
Popović, Sanda; Buljevac, Marko (2016), »Prekid srednjoškolskog obrazovanja mladih s teškoćama u razvoju«, Ljetopis socijalnog rada, 23(3), str. 463-488. doi: https://doi.org/10.3935/ljsr.v23i3.108

Ristić Dedić, Zrinka; Jokić, Boris (2014), Izvještaj br. 1, Uče li, koliko i što učenici četvrtog i osmog razreda? Pišu li i kada domaće zadaće?, serija »O učenju 2014. «, Zagreb: Institut za društvena istraživanja u Zagrebu, str. 1-13. Dostupno na: https://www.idi.hr/ucenje2014/izvjestaj1.pdf [1. 12. 2020.]

Ristić Dedić, Zrinka; Jokić, Boris (2014), Izvještaj br. 3. Kakva je podrška učenju u školi? Pružaju li roditelji podršku djeci u učenju? Zašto učenici uče?, serija »O učenju 2014.«, Zagreb: Institut za društvena istraživanja u Zagrebu, str. 1-24. Dostupno na: https://www.idi.hr/ucenje2014/izvjestaj3.pdf [1. 12. 2020.]

Schumm, Jeanne Shay; Vaughn, Sharon (1992), »Planning for mainstreamed special education students: Perceptions of general classroom teachers «, Exceptionality, 3(2), str. 81-98. doi: https://doi.org/10.1080/09362839209524799

Schumm, Jeanne; Vaughn, Sharon; Haager, Diane; McDowell, Judith; Rothlein, Liz; Saumell, Linda (1995), »General education teacher planning: What can students with learning disabilities expect?« Exceptional Children, 61, str. 335-352. doi: https://doi.org/10.1177/001440299506100403

Spevec, Dubravka; Vuk, Ružica (2012), »Demografski resursi i potencijali te organizacija primarnog obrazovanja u Krapinsko-zagorskoj županiji«, Hrvatski geografski glasnik, 74(1), str. 187-212.

Svilan, Dominko (2019), »Rad s učenicima s teškoćama u razvoju u nastavi geografije«, diplomski rad, mentor: Pejdo, Ana, Sveučilište u Zadru, Odjel za geografiju, str. 1-74.

Planinc Resnik, Tatjana; Kolnik, Karmen (2016), »Working with students with special educational needs: Views and experiences of geography teachers«, Dela, 46, str. 105-122.

Torma, Luka (2018), »Individualni pristup učenicima sa specifičnim teškoćama u učenju u nastavi Geografije«, diplomski rad, mentor: Hrvatić, Neven, Sveučilište u Zagrebu, Prirodoslovno-matematički fakultet, str. 1-53.

Training and Development Agency for Schools (2009), Including pupils with SEN and/or disabilities in primary Geography, for primary PGCE tutors and trainees, Manchester, str. 1-28. Dostupno na: https://dera.ioe.ac.uk/13792/1/geography.pdf [1. 12. 2020.]

Velki, Tena (2018), Priručnik za rad s hiperaktivnom djecom u školi: Za učitelje, roditelje $i$ asistente $u$ nastavi, Zagreb: Naklada Slap.

Velki Tena; Romstein Ksenija (2015), Učimo zajedno, priručnik za pomoćnike u nastavi za rad s djecom s teškoćama u razvoju, Osijek: Fakultet za odgojne i obrazovne znanosti Sveučilišta Josipa Jurja Strossmayera.

Vican, Dijana; Karamatić Brčić, Matilda (2013), „»Obrazovna inkluzija u kontekstu svjetskih i nacionalnih obrazovnih politika«, Život i škola, 30(2), str. 48-66. 
Vranković, Biljana (2017), Geografski aspekt razvoja mreže osnovnih škola u Hrvatskoj, doktorska disertacija, mentorica: Vuk, Ružica, Prirodoslovno-matematički fakultet, Zagreb.

Zrilić, Smiljana; Brzoja, Kristina (2013), »Promjene u pristupima odgoju i obrazovanju učenika s teškoćama«, Magistra Iadertina, 8(1), str. 141-153. doi: https://doi.org/10.15291/magistra.785

\section{GEOGRAPHY'S TEACHERS ATTITUDES TOWARDS WORKING WITH PUPILS WITH DEVELOPMENTAL DIFFICULTIES}

\section{Dominko Svilan, Ana Pejdo, Jadranka Brkić-Vejmelka}

For successful application of educational inclusive concept, next to the material and technical requirements, of high importance is also the quality and improvement of educational practice, education and competence of all participants in the educational process. Teachers are crucial part of the educational process so their acquired knowledge and skills are of great importance for the success of the inclusive education. Aim of this paper was to determine geography teacher's attitudes towards working with pupils with developmental difficulties. For the purpose of the research survey was conducted including geography teachers in elementary and secondary schools in Croatia. Research results indicate that teachers do not consider themselves educated enough neither competent for everyday work with pupils with developmental difficulties and they express the need for additional education. In their school work they try to adopt teaching materials and methods according to children's difficulties. Cooperation with school professional and pedagogical service and parents is one of the main preconditions for successful teaching. There are significant differences in teacher's attitudes in elementary in relation to ones in secondary schools.

Keywords: pupils with developmental difficulties, Geography, teaching, teacher's attitudes 